for 30 minutes. The new Order contains a number of other provisions and administrative requirements for carrying it out. As it will affect large numbers of people, Sir Kingsley Wood has also issued an explanatory Memorandum setting out in non-technical language the effect of the Order and the way in which it will work ${ }^{2}$.

Bacteriological standards were prescribed for the various elasses of graded milk under the Order of 1923, namely, 'Certified' and 'Grade A. (Pasteurised)' must not contain more than 30,000 bacteria per c.c. and must not contain coliform bacilli in 1/10 c.c., 'Grade A. (Tuberculin Tested)' and 'Grade A' must not contain more than 200,000 bacteria per c.c. nor coliform bacilli in 1/100 c.c., and 'Pasteurised' must not contain more than 100,000 organisms per c.c., and the conditions for sampling and testing were standardised by the Ministry of Health so far as possible, so that it was hoped that reasonably concordant results might be obtained by different analysts. It was found in practice, however, that reputable workers employing a similar technique obtained the most discordant results, and a critical inquiry into the validity of the methods available for the bacteriological grading of milk was carried out for the Medical Research Council by Prof. G. S. Wilson and his assistants ${ }^{3}$. It was found that the plate count test for numbers of bacteria breaks down on account of the irregularity of distribution and clumping of the organisms in the milk, so that, under the best conditions, on any count an allowance of \pm 90 per cent may have to be made. Much the same may be said of the coliform test, except for pasteur. ised milk, when it may be of some value, serving as an index of the efficiency of the processing if performed with the freshly pasteurised milk. The new Order, therefore, while prescribing plate count tests for raw 'Tuberculin Tested' and 'Accredited' milks until December 31, 1936, substitutes for them a methylene blue reduction test for these milks on and after January 1, 1937. In addition, a coliform test is prescribed for these milks. Plate counts are to be continued for 'Tuberculin Tested Milk (Pasteurised)' and for 'Pasteurised' milk, the method of carrying out these tests being the same as obtains at present (Memo. 139/Foods). The methylene blue reduction test was the subject of much experimental work by Prof. Wilson and his colleagues, and appeared to fulfil most of the requirements demanded of a test for routine grading of raw milk. It is a simple test, with a very small experimental error, can be carried out by relatively unskilled workers on a large number of samples, and requires little equipment. By means of it, milk can be classified into the three or four grades necessary on the basis of cleanliness, it affords a useful index of the keeping qualities and gives more information about the milk than does the plate count. Allusion is also made to the possible use of the phosphatase test of Kay and Graham for the detection of imperfect pasteurisation.

1 Ministry of Health: Statutory Rules and Orders 1936. No 356. 4d. net. Circular 1533. 2d. net. (London: H.M. Stationery Office, 1936.)

Sale of Milk under Special Designations. Memo. 197/Foods. 3d. net.

3 Medical Research Council. Special Report Series, No. 206: The Bacteriological Grading of Milk. By $G$. S. Wilson, assisted by $R$. S. Bacteriological Grading of Milk. By G. S. Wilson, assisted by R. S.
Twigg, R. C. Wright, C. B. Hendry, M. P. Cowell and I. Maier. Pp. Twigg, R. C. Wright, C. B. Hendry, M. P. Cowell and I. Mai

\title{
Transitional Cultures in the Stone Age
}

A STUDY of the late palæolithic, mesolithic and early neolithic periods, of which the conclusions point to the necessity of a reclassification and further refinement in the definition of their characteristic industries, is based by M. Laurent Coulonges on his exploration of the prehistoric sites of Sauveterre-la. Lémance (Lot-et-Garonne). His report on his excavations and discussion of the evidence are published by the Institut de Paléontologie Humaine (Archives, Mém. 14).

Two sites were under investigation. They are situated on either side of the Paris-Agen railway in the valley of the Lémance, a tributary of the Lot, in the Canton of Fumel in the north-east of the department. One of the sites consists of two rock shelters on the south side of a detached island of the Cretaceous limestone, known as Le Martinet. They were first brought to light in 1868 when the railroad was under construction. M. Coulonges began excavation here in 1923. The second site, situated 300 metres away to the north, is a rock-shelter on the north side of the Roc Allan beside the Périgueux road.

Le Martinet. On this site ten different levels were clearly to be distinguished. Its importance lies in the fact that here, for the first time, was found on one and the same site a stratigraphic succession of Upper Palæolithic, Mesolithic and Neolithic. Of the various levels, the first was archæologically sterile, as was the third; the second level is Upper Palæolithic, the fourth, fifth and sixth, Mesolithic, the seventh, Neolithic, and the eighth, Iron Age and GalloRoman, with sub-soil and soil above.

In regard to cultures, that of Level 2 is Upper Magdalenian, but with certain resemblances to Azilian, more especially the Azilian of the Dordogne, and it is, therefore, here regarded as a proto-Azilian. In the Mesolithic three stages are differentiated. Level 4 contains a characteristic Azilian industry in demonstrable relations to palæolithic types; and sharply contrasting with them is a considerable number of microlithic implements in a great variety of types in pygmy form. For this industry the specific name of Sauveterrian is adopted. It is followed in Level 5 by what is obviously the industry of a new race, differing in its culture and habits from the Sauveterrian. There is, for example, for the first time in this station, the evidence of a hut site. This is Tardenois I, and unlike Sauveterrian which clearly represents a local development, it is an intrusive culture from outside. In this the most typical and characteristic implement is the trapezoidal barbpoint (pointe-barbelure). The industry is free from extraneous influence, a fact perhaps most patently indicated by the striking absence of the characteristic small triangular forms of the Sauveterrian.

The cultural break between Levels 4 and 5 is also marked in the fauna, the presence of the beaver and Helix nemoralis in quantity in Level 4 pointing to a period of humidity. 
Immediately above Tardenois I is Tardenois II in Level 6. Here appear the true trapeze, half-moons, the small implements with transverse cutting-edge and the first indications in technique of the approaching Neolithic, to which the next level belongs.

Tardenois III, the first neolithic phase, appears in Level 7, in which there are several hut-sites, clearly of the same age, with an abundance of implements. The technique is essentially the same as that of the two preceding Tardenois industries, but the cores and scrapers are larger and the large burins, planes and picks, and other forms characteristic of a neolithic industry appear. There are no polished implements. Pottery, absent in the lower levels, is abundant. The forms cannot be reconstructed, owing to the fragmentary condition of the finds; but the ornament is either impressed with the finger, in relief, or incised in horizontal lines and bands, or in the incised ornament, in oblique lines. It resembles pottery with impressed or incised ornament from Spain, France (Gard, Aude, Drôme, Lozère), Swiss lake dwellings and the beginnings of æneolithic and bronze in Belgium. Art is represented by an important human mask in calcareous stone, resembling the figures of the menhirs, and a phallic bisexual object. The culture appears to be advanced neolithic, bordering on the æneolithic.

Le Roc Allan. Here on the second site no less than nineteen levels have been distinguished, extending from Magdalenian to the modern surface. Except in the Azilian and the Sauveterrian the deposits are thin. Impressions of leaves from Tardenois levels have been identified and indicate a vegetation in mesolithic times comparable to that of to-dayHedera, Ruscus, Ilex, Populus, Ulmus, Quercus, Corylus, Acer. The industries of the various levels follow those of Le Martinet sufficiently closely to call for no special comment here.

The results of these excavations, and especially the stratigraphy of mesolithic industries, constitute a contribution of the first importance to prehistoric science. As M. Coulonges points out, not only does it throw light on the development of the Tardenoisian industry and on its differentiation and chronology in relation to other cultures; but it also makes possible for the first time the characterisation of a new industry, often confused with the Tardenoisian, namely, the Sauveterrian. The Tardenoisian itself, which has often been regarded, in the absence of stratigraphic evidence, as merely a form or type, must now be regarded as a widely distributed and distinct culture, not entirely microlithic, but one in which the trapezoidal implement, if characteristic, is associated with forms which conform to the normal in size. From this must be distinguished the Sauveterrian, an industry with which triangular microliths are associated, and derived from the Upper Palæo. lithic.

In Tardenois I two types are distinguished, a coastal which appears at Mugem in Portugal and in the Morbihan, with widely spread affinities, of which the racial type is seen in the short dolichocephals of Mugem, and a continental, which appears at Le Martinet and in the Tardenois of Central Germany, of which the racial type is the skeleton of Cuzoul de Gramat.

Since the distinction to be drawn between Sauve. terrian and Tardenoisian has been pointed out, its existence has been notified from a large number of stations generally distributed over France. The racial type is the man of Roc-du-Barbeau (Dordogne).

The classification which M. Coulonges now proposes is as follows.

Final Paloeolithic: (1) Upper Magdalenian; Proto-Azilian.

Mesolithic: (1) Azilian, subdivided into a Perigordian facies and a Pyrenean facies; (2) Sauve. terrian, subdivided into Extended Aurignacian, Extended Magdalenian (rare), and Final Azilian; (3) Tardenois I, subdivided into coastal and con. tinental ; (4) Tardenois II.

Neolithic: Tardenois III and the civilisations of the polished axe.

\section{Elements beyond Uranium}

$\mathrm{T}$ $\mathrm{HE}$ possibility of producing elements with atomic numbers greater than 92 was discussed in 1934 by Fermi and his colleagues, who found that nearly all the elements undergo some transformation when bombarded with neutrons, and it was claimed that, among the products derived from uranium in this process, two at least, with half-life periods of 13 minutes and 90-100 minutes, must lie in the unknown range beyond uranium.

In view of the fact that this claim was challenged by von Grosse and Agruss (Nature, 134, 773, November 17,1934$)$, who declared that the 13minute radio-element must be an isotope of protactinium, it is interesting to read in the April issue of the Berichte der deutschen chemischen Gesellschaft that Profs. Otto Hahn and Luise Meitner and Herr F. Strassmann have found substantial support for Fermi's contention by devising a satisfactory chemical method of separating the products of bombardment of uranium from known elements and to some extent from one another. Thus the so-called 13-minute and 100-minute products are both precipitated by hydrogen sulphide from strong acid solutions containing either platinum or rhenium as carriers, whereas elements Nos. 90-92 all remain dissolved. Moreover, they do not share with protactinium (No. 91) the characteristic property of co-precipitation with zirconium phosphate. Thus it is concluded that they are trans-uranic elements. That they are not themselves isotopes follows from the fact that they can be separated by means of sodium hydroxide.

Further examination has shown that the half-life periods have been incorrectly estimated, and that the longer-lived product is a mixture of homologues of the platinum group (Nos. 94-96). These can all be separated from eka-rhenium (No. 93) by precipitation in acid solution by platinum foil. Alto. gether five or six trans-uranic radio-elements have been detected, namely, two isotopes of eka-rhenium, two of eka-osmium, one of eka-iridium and perhaps one of eka-platinum, the corresponding half-life periods being 16 minutes, $2 \cdot 2$ minutes, 12 hours, 59 minutes, 3 days and about 3 hours. The first and third of these are produced only by 'fast' neutrons, 